\title{
Mixing control on the photosynthesis-irradiance relationship and an estimate of primary production in the winter of the East China Sea
}

\author{
Gwo-Ching Gong * Tzong-Yueh Chen, and Wan-Lynn You
}

Institute of Marine Environment and Ecology, National Taiwan Ocean University, Keelung, Taiwan

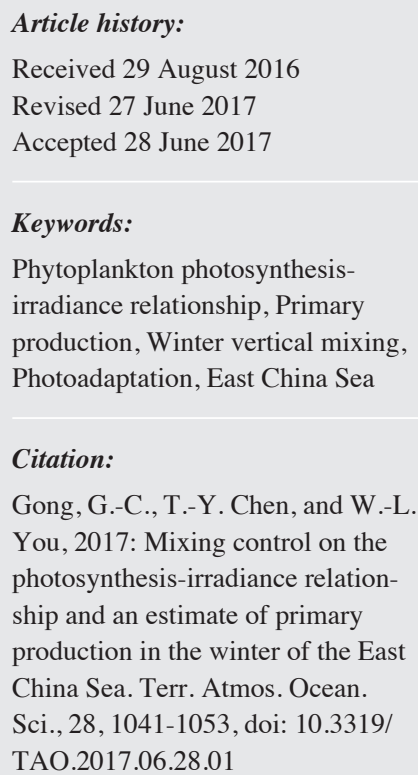

Received 29 August 2016

Revised 27 June 2017

Accepted 28 June 2017

Keywords:

Phytoplankton photosynthesisirradiance relationship, Primary production, Winter vertical mixing, Photoadaptation, East China Sea

Citation:

Gong, G.-C., T.-Y. Chen, and W.-L. You, 2017: Mixing control on the photosynthesis-irradiance relationship and an estimate of primary production in the winter of the East China Sea. Terr. Atmos. Ocean.

Sci., 28, 1041-1053, doi: 10.3319/

TAO.2017.06.28.01

\begin{abstract}
The response of marine phytoplankton primary productivity to available light (photosynthesis-irradiance relationship, $\mathrm{P}^{\mathrm{B}}$-E curve) is the principle physiology of plant that is particularly important in the estimation of primary production and in physicalbiogeochemical modeling. In this study, we conducted on-board incubation experiments to examine photosynthesis-irradiance relationships in samples collected from the subtropical shelf of the East China Sea during a winter cruise. Depth and spatial variation of the maximum photosynthesis rate normalized to chlorophyll $a\left(P_{m}^{B}\right)$ and the initial slope $(\alpha)$ of the $\mathrm{P}^{\mathrm{B}}$-E curve parameters were insignificant in the East China Sea. The vertical homogeneity was due to the strong winter mixing. However, spatial homogeneity could be possibly caused by different factors. With relatively low solar radiation in the winter, strong vertical mixing deteriorated light dose and may lead to homogeneously low photosynthetic parameters. In addition, differential inhibitions by temperature and nutrient availability may potentially cause the spatial homogeneity. The mean values of $P_{m}^{B}$ and $\alpha$ were $2.82 \pm 0.50 \mathrm{gC}(\mathrm{gChl})^{-1} \mathrm{~h}^{-1}$ and $0.010 \pm 0.002 \mathrm{gC}$ $(\mathrm{gChl})^{-1} \mathrm{~h}^{-1}$ ( $\mathrm{mol}$ photons $\left.\mathrm{m}^{-2} \mathrm{~s}^{-1}\right)^{-1}$, respectively. Using the photosynthetic-irradiance model ( $\mathrm{P}^{\mathrm{B}}$-E curve model), the estimated value of shelf-averaged euphotic zone integrated primary production was $186 \pm 117 \mathrm{mgC} \mathrm{m}^{-2} \mathrm{~d}^{-1}$. With an overestimate of satellite-derived primary production, field observations will be required.
\end{abstract}

\section{INTRODUCTION}

The relationship of phytoplankton photosynthesis to irradiance is useful to predict primary production over large areas in the world's ocean (Platt and Sathyendranath 1988; Behrenfeld and Falkowski 1997). The photosynthesisirradiance $\left(\mathrm{P}^{\mathrm{B}}-\mathrm{E}\right)$ curve, with $\mathrm{P}^{\mathrm{B}}$ representing the primary productivity normalized to chlorophyll, describes the physiological response of phytoplankton photosynthesis to various light intensities (Nielsen 1952). The general trend of $\mathrm{P}^{\mathrm{B}}-\mathrm{E}$ curve shows a linear increase of $\mathrm{P}^{\mathrm{B}}$ with increasing light intensity at low light levels and gradually increasing to a saturation phase at high light levels. Beyond the saturation phase, a photoinhibition phase might occur at extremely high light levels. The $\mathrm{P}^{\mathrm{B}}$-E curve can be formulated using a mathematical function with or without photoinhibition (e.g., Webb et al. 1974; Platt et al. 1980) by the photosynthetic parameters $\left(P_{m}^{B}\right.$ and $\left.\alpha\right)$ fitted from the $\mathrm{P}^{\mathrm{B}}$-E curve. $P_{m}^{B}$ rep-

\footnotetext{
* Corresponding author

E-mail: gcgong@ntou.edu.tw
}

resents the maximum rate of primary productivity normalized to chlorophyll, and $\alpha$ represents the initial slope of $\mathrm{P}^{\mathrm{B}}$-E curve. Therefore, the photosynthetic parameters are widely used in the estimation of regional and global primary production when satellite data are available (Platt and Sathyendranath 1993; Longhurst et al. 1995; Sathyendranath et al. 1995; Gong et al. 1999, 2001). Moreover, the photosynthetic parameters also play a key role in the coupled physicalbiogeochemical model (e.g., Liu et al. 2010).

The East China Sea (ECS) is one of the largest marginal seas with a wide continental shelf in the northwest Pacific. The large amount of enriched nutrient from the Changjiang (Yangtze River) runoff together with the coastal upwelling effect (Gong et al. 1995, 2003; Chen et al. 2004) favors catches of Chinese marine fisheries (Watson and Pauly 2001). However, global warming and human activities have caused a rapid rise in seawater temperatures and eutrophication in the ECS and this has had an enormous impact on the ocean ecosystem. Over the last ten years the temperature of the ECS has increased about $1^{\circ} \mathrm{C}$, close to eight times 
that of average global temperature (Trenberth et al. 2007). From the 1960s to the 1990s, Wang (2006) found a 5-fold increase in input of dissolved inorganic nitrogen from the Yangtze River causing adverse changes to the ECS ecosystem, including harmful algal blooms. Cultural eutrophication and hypoxia, in particular excessive growth of algae, are the responses to increasing nutrient discharge to the water body (Chen et al. 2007; Rabouille et al. 2008; Chou et al. 2009; Cai et al. 2011; Wang et al. 2012). In addition, the construction of the Three-Gorges Dam might also have caused a reduction of freshwater input and changes in sediment flux, resulting in a shift of phytoplankton composition and a shrinking of primary production in the ECS (Gong et al. 2006). Moreover, extreme weather conditions and severe floods have triggered an increase discharge of excessive terrigenous material into the coastal ocean (Gong et al. 2011). Such changes can have a serious impact on primary production, which is the base of the marine food web, and consequently affect the catches of marine fisheries. Therefore, it is important to be able to obtain accurate information about the primary production to get a clearer understanding of the whole ecosystem. There were numerous studies regarding primary production in the ECS (e.g., Gong et al. 2001, 2006; Chen et al. 2004). However, there was very limiting data about the photosynthetic parameters in the winter of the ECS. In this study, we first reported the characteristics of $\mathrm{P}^{\mathrm{B}}-\mathrm{E}$ curves through the whole ECS during the winter. Then we compared the primary production derived from our photosynthetic parameters with the spatial distribution of primary production obtained from the standard products of satellite-derived ocean color primary production (http:// www.science.oregonstate.edu/ocean.productivity/).

\section{MATERIALS AND METHODS}

\subsection{Study Area and Sampling}

The cruise for this study was carried out in the East China Sea on $R / V$ Ocean Researcher I 2 - 11 January 2008 (Cruise no. 855). Data were collected from 25 stations in four transects (Fig. 1). Water samples were taken at six depths with CTD (Seabird Inc., USA) and a Rosette sampler (General Oceanics Inc., USA) using 20 L Teflon coated X-Niskin bottles.

At each sampling station, incident photosynthetically active radiation (PAR) above sea surface and depth profile of underwater PAR, temperature, salinity, water density, nutrients and chlorophyll $a(\mathrm{Chl} a)$ concentrations were measured. Time course of PAR above sea surface was measured using an irradiance meter (QSR2100; Biospherical Inc., USA) and depth profile of underwater PAR was measured using a submersible PAR sensor (Chelsea Technologies Group Ltd) mounted on the CTD device. From the depth profile of PAR, we were able to derive the mean attenuation coefficient $\left(\mathrm{K}_{\mathrm{d}}\right)$. Euphotic zone depth, defined as the depth of $1 \%$ surface light penetration, was $4.605 / \mathrm{K}_{\mathrm{d}}$. The euphotic depth $\left(Z_{\mathrm{e}}\right)$ for the stations visited at night was calculated based on the relationship between $\mathrm{Z}_{\mathrm{e}}$ and water depth (BD) $\left(Z_{e}=0.49 \times B D-8.3, n=9, p<0.05, R^{2}=0.87\right)$. For depths greater than $200 \mathrm{~m}, \mathrm{Z}_{\mathrm{e}}$ was derived from the relationship between chlorophyll concentration and euphotic depth, as

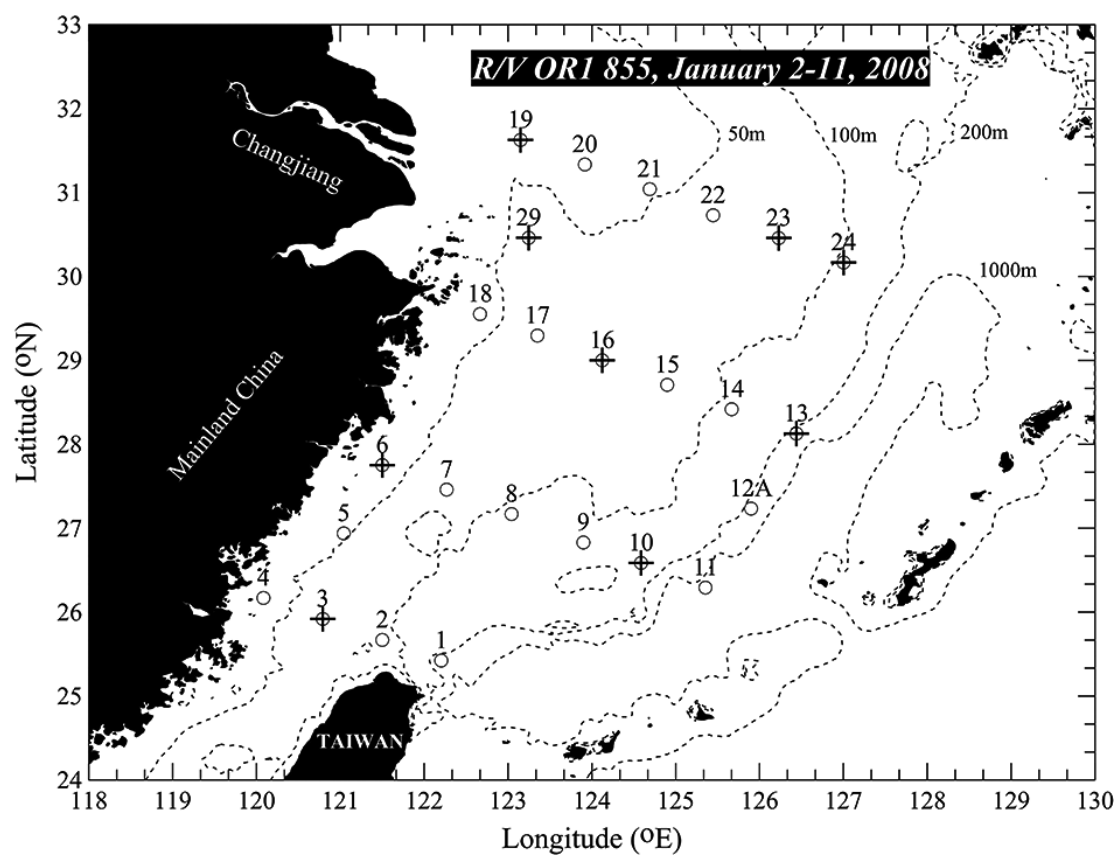

Fig. 1. Sampling stations in the ECS study area (open circles). On-board $\mathrm{P}^{\mathrm{B}}$-E curve experiments were performed at stations marked with a cross . Dashed lines indicate the 50,100, 200, and $1000 \mathrm{~m}$ isobaths, respectively. 
proposed previously by Morel and Maritorena (2001). Mixed layer depth was defined as a surface layer with a density variation of less than $0.1 \mathrm{~kg} \mathrm{~m}^{-3}$ (Gong et al. 1999).

\subsection{Photosynthesis-Irradiance Experiments and Models}

The analytical methods used to determine nutrient and $\mathrm{Chl} a$ concentrations are described in detail elsewhere (Gong et al. 2003, 2011). At the nine sampling stations (cross symbols, Fig. 1), primary productivity was measured by the ${ }^{14} \mathrm{C}$ assimilation method (Parsons et al. 1984). The $\mathrm{P}^{\mathrm{B}}$-E curve at each sampling depth was constructed in a seawater-cooled incubator with artificial illumination $(1000 \mathrm{~W}$ submersible halogen quartz lamp). Samples were incubated for two hours. In total, nine different light levels (E) 2000, $1365,950,800,480,400,260,130,65 \mu$ Einstein $\mathrm{m}^{-2} \mathrm{~s}^{-1}[1$ Einstein $(\mathrm{E})=1 \mathrm{~mol}$ photons] of PAR as well as one dark bottle were set in the incubator. Samples were measured in duplicate at each light level. Equation (1) or (2a) was used to fit the experimental $\mathrm{P}^{\mathrm{B}}$-E curve results of each depth of the sampling station to estimate the parameters $P_{m}^{B}$ and $\alpha$ (Platt et al. 1980). Then, the light saturation index $\left(\mathrm{E}_{\mathrm{k}}\right)$ can be defined as $P_{m}^{B} / \alpha$.

$P^{B}(z)=P_{m}^{B}(z)\left[1-e^{-\frac{\alpha(z) E}{P_{m}^{B}(z)}}\right]$

$P^{B}(z)=P_{s}^{B}(z)\left[1-e^{-\frac{\alpha(z) E}{P_{s}^{B}(z)}}\right]\left[e^{-\frac{\beta(z) E}{P_{s}^{B}(z)}}\right]$

$P_{m}^{B}(z)=P_{s}^{B}(z)\left[\frac{\alpha(z)}{\alpha(z)+\beta(z)}\right]\left[\frac{\beta(z)}{\alpha(z)+\beta(z)}\right]^{\beta(z) / \alpha(z)}$

Using Eqs. (3a) or (3b), we calculated primary productivity at various depths $[P P(z)]$ at each station.

$$
\begin{aligned}
& P P(z)=\int_{0}^{t} \operatorname{Chl}(z) P_{m}^{B}(z)\left[1-e^{-\frac{\alpha(z) E(z, t)}{P_{m}^{B}(z)}}\right] d t \\
& P P(z)=\int_{0}^{t} \operatorname{Chl}(z) P_{s}^{B}(z)\left[1-e^{-\frac{\alpha(z) E(z, t)}{P_{s}^{B}(z)}}\right] e^{-\frac{\beta(z) E(z, t)}{P_{s}^{B}(z)}} d t
\end{aligned}
$$

where $E(z, t)=E_{0}(t) e^{-\left(K_{d} z\right)}, E_{0}(t)$ is incident PAR above sea surface during the day, $K_{d}$ is mean attenuation coefficient of PAR within the euphotic zone, and $t$ is the time from sunrise to sunset.

The euphotic zone integrated primary production $(I P)$ at each station was integrated from Eq. (3b) as following:

$I P=\int_{0}^{Z_{e}} P P(z) d z$

Unless otherwise indicated, variation around each mean is presented as \pm 1 standard deviation.

\section{RESULTS}

General information about the cruise and the mean marine environmental condition values (hydrography, nutrients, and $\mathrm{Chl} a$ ) within the mixed layer of each station were listed in Table 1 and were described below.

\subsection{Incident Photosynthetic Active Radiation Above Sea Surface}

The daily incident PAR above sea surface measured during the cruise was shown in Fig. 2. The high variation of the daily incident PAR reflected the rough winter weather caused by the northeasterly winds and a cold front. The average number of hours of light was about $11 \mathrm{hr}$, and daily total PAR $\left(\mathrm{E}_{\mathrm{T}}\right)$ varied between 9.6 and $35.3 \mathrm{E} \mathrm{m}^{-2} \mathrm{~d}^{-1}$. The mean value of daily averaged PAR and total PAR were $557 \pm 238 \mu \mathrm{E} \mathrm{m}^{-2} \mathrm{~s}^{-1}$ and $22.3 \pm 9.6 \mathrm{E} \mathrm{m}^{-2} \mathrm{~d}^{-1}$, respectively (Table 1).

\subsection{Spatial Distribution of Euphotic Depth $\left(Z_{e}\right)$ and Mixed Layer Depth (MLD)}

The spatial distribution of euphotic depth and mixed layer depth were shown in Fig. 3a. $Z_{\mathrm{e}}$ ranged from $8-79 \mathrm{~m}$, corresponding to a $K_{d}$ between 0.599 and $0.058 \mathrm{~m}^{-1}$. The spatial variation of euphotic depth, from northwest toward southeast, followed a similar trend as the isobaths. The MLD varied between 10 and $124 \mathrm{~m}$ in the same direction. Although the variation of MLD was less evident than euphotic depth, we still observed a depth change from the inner continental shelf toward the outer shelf. The MLD was deeper than the euphotic depth at most of the stations where on-board $\mathrm{P}^{\mathrm{B}}-\mathrm{E}$ curve experiments were conducted (Table 2).

\subsection{Hydrography, Nutrients, and Chlorophyll}

Figures $3 \mathrm{~b}$ and $\mathrm{c}$ showed the mean seawater temperature, salinity, nutrients (total inorganic nitrogen, phosphate, and silicate), and Chl $a$ concentration in the MLD. The seawater temperature varied between $12.1-24.2^{\circ} \mathrm{C}$ with an average of $18.1 \pm 3.4^{\circ} \mathrm{C}$, and salinity ranged from $30.81-34.56$ with an average of $33.81 \pm 1.06$. The spatial variation of seawater temperature and salinity showed an increasing trend from northwest toward southeast forming the gamma-shape (Fig. 3b). This phenomenon is thought to be caused by the intrusion of warm and saline Kuroshio water in the winter season (Beardsley et al. 1985; Gong et al. 2003). The total inorganic nitrogen concentration ranged from $1.1-25.5 \mu \mathrm{M}$ with an average of $6.8 \pm 6.0 \mu \mathrm{M}$, the concentration of phosphate was less than $0.85 \mu \mathrm{M}$ with an average of $0.28 \pm 0.24$ $\mu \mathrm{M}$, and silicate concentration ranged from $2.3-27.6 \mu \mathrm{M}$ 
with an average of $10.1 \pm 7.2 \mu \mathrm{M}$. The spatial distribution patterns were similar to the patterns found for temperature and salinity (Figs. 3c and d), where low temperature and low salinity were associated with high nutrient concentrations. The pattern of spatial distribution of $\mathrm{Chl} a$ concentration did not resemble from those hydrography or nutrients. The Chl $a$ concentrations varied between 0.26 and $1.10 \mathrm{mg}$ $\mathrm{m}^{-3}$ and had an average of $0.63 \pm 0.20 \mathrm{mg} \mathrm{m}^{-3}$ (Fig. 3d). In contrast to the surrounding environment, station 1 showed a slightly higher Chl $a$ concentration, probably caused by the Kuroshio upwelling (Gong et al. 1995, 2001).

\subsection{Characteristics of $\mathrm{P}^{\mathrm{B}}$-E Curves and Euphotic Zone Integrated Primary Production}

The results of $\mathrm{P}^{\mathrm{B}}-\mathrm{E}$ curves from each of the nine sampling stations and the values of photosynthetic parameters fitted from Eq. (2) were shown in Fig. 4 and Table 2, respectively. In general, photoinhibition was not very clear in the $\mathrm{P}^{\mathrm{B}}-\mathrm{E}$ curves. $P_{m}^{B}$ within the MLD was between 1.05 - $3.90 \mathrm{gC}(\mathrm{gChl})^{-1} \mathrm{~h}^{-1}$ with a median and a mean of 2.82 and $2.76 \pm 0.63 \mathrm{gC}(\mathrm{gChl})^{-1} \mathrm{~h}^{-1}$, respectively. For all stations, no significant changes of $P_{m}^{B}$ were observed with increasing depth, except at the most northeastern sampling station (station 24), where $P_{m}^{B}$ decreased as depth increased. $\alpha$ was between 0.003 and $0.012 \mathrm{gC}(\mathrm{gChl})^{-1} \mathrm{~h}^{-1}\left(\mu \mathrm{E} \mathrm{m}^{-2} \mathrm{~s}^{-1}\right)^{-1}$ with a median and a mean of 0.009 and $0.009 \pm 0.002 \mathrm{gC}(\mathrm{gChl})^{-1} \mathrm{~h}^{-1}$ $\left(\mu \mathrm{E} \mathrm{m}^{-2} \mathrm{~s}^{-1}\right)^{-1}$, respectively. The light saturation index $\left(E_{K}=P_{m}^{B} / \alpha\right)$, which is a convenient indicator of phytoplankton photoacclimational status (Sakshaug et al. 1997), varied between 188 and $402 \mu \mathrm{E} \mathrm{m}^{-2} \mathrm{~s}^{-1}$ with a median and a mean of 324 and $307 \pm 60 \mu \mathrm{E} \mathrm{m}^{-2} \mathrm{~s}^{-1}$, respectively.

Depth variation of primary productivity in the stations where $\mathrm{P}^{\mathrm{B}}$-E curve experiments were conducted can be calculated by Eq. (3) and its euphotic zone integrated primary production (IP) can be obtained by Eq. (4). The values of

Table 1. General information of the cruise and the mean values of environmental conditions (hydrography, nutrients and chlorophyll) within the mixed layer at each station.

\begin{tabular}{|c|c|c|c|c|c|c|c|c|c|c|c|c|c|c|c|c|c|c|c|}
\hline \multirow{2}{*}{$\begin{array}{c}\text { Station } \\
\text { no. }\end{array}$} & \multirow{2}{*}{$\begin{array}{l}\text { Lon } \\
\left({ }^{\circ} \mathbf{E}\right)\end{array}$} & \multirow{2}{*}{$\begin{array}{l}\text { Lat } \\
\left({ }^{\circ} \mathbf{N}\right)\end{array}$} & \multirow{2}{*}{$\begin{array}{l}\text { BD } \\
(\mathbf{m})\end{array}$} & \multirow{2}{*}{$\begin{array}{c}\mathbf{E}_{\mathrm{T}}(\mathbf{E} \\
\left.\mathbf{m}^{-2} \mathbf{d}^{-1}\right)\end{array}$} & \multirow{2}{*}{$\underset{\left(\mathbf{m}^{-1}\right)}{\mathbf{K}_{\mathbf{d}}}$} & \multirow{2}{*}{$\begin{array}{c}\mathbf{Z}_{\mathrm{e}} \\
(\mathbf{m})\end{array}$} & \multirow{2}{*}{$\begin{array}{c}\text { MLD } \\
\text { (m) }\end{array}$} & \multicolumn{2}{|c|}{$\mathbf{T}\left({ }^{\circ} \mathbf{C}\right)$} & \multicolumn{2}{|c|}{ 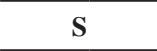 } & \multicolumn{2}{|c|}{ TIN ( $\boldsymbol{\mu M})$} & \multicolumn{2}{|c|}{$\mathrm{PO}_{4}(\mu \mathrm{M})$} & \multicolumn{2}{|c|}{$\mathrm{SiO}_{4}(\mu \mathrm{M})$} & \multicolumn{2}{|c|}{ Chl $a\left(\mathrm{mg} \mathrm{m}^{-3}\right)$} \\
\hline & & & & & & & & mean & $\boldsymbol{\sigma}$ & mean & $\boldsymbol{\sigma}$ & mean & $\boldsymbol{\sigma}$ & mean & $\sigma$ & mean & $\sigma$ & mean & $\sigma$ \\
\hline 1 & 122.204 & 25.423 & 262 & 33.7 & 0.15 & 31 & 10 & 20.51 & 0.18 & 34.36 & 0.01 & 3.3 & 1.0 & 0.44 & 0.37 & 6.0 & 0.0 & 1.100 & 0.022 \\
\hline 2 & 121.501 & 25.668 & 106 & 33.7 & 0.10 & 46 & 69 & 19.39 & 0.01 & 34.49 & 0.00 & 5.7 & 1.5 & 0.21 & 0.01 & 6.8 & 0.1 & 0.523 & 0.012 \\
\hline 3 & 120.791 & 25.919 & 76 & 9.6 & 0.19 & 25 & 40 & 18.47 & 0.01 & 33.55 & 0.00 & 8.0 & 1.6 & 0.29 & 0.03 & 10.7 & 0.4 & 0.549 & 0.293 \\
\hline 4 & 120.083 & 26.169 & 37 & 9.6 & 0.51 & 10 & 20 & 14.68 & 0.08 & 31.13 & 0.08 & 20.7 & 9.9 & 0.85 & 0.03 & 25.7 & 0.4 & 0.486 & 0.040 \\
\hline 5 & 121.040 & 26.938 & 51 & 15.8 & 0.33 & 14 & 18 & 15.82 & 0.01 & 32.81 & 0.01 & 12.2 & 5.7 & 0.48 & 0.01 & 17.1 & 0.1 & 0.530 & 0.011 \\
\hline 6 & 121.501 & 27.752 & 30 & 15.8 & 0.60 & 8 & 19 & 13.48 & 0.03 & 30.81 & 0.03 & 25.5 & 3.2 & 0.79 & 0.06 & 27.6 & 0.2 & 0.456 & 0.066 \\
\hline 7 & 122.268 & 27.460 & 89 & 15.8 & 0.12 & 37 & 68 & 18.98 & 0.04 & 34.41 & 0.00 & 5.0 & 1.5 & 0.14 & 0.03 & 6.7 & 0.1 & 0.862 & 0.012 \\
\hline 8 & 123.042 & 27.169 & 109 & 15.8 & 0.10 & 47 & 77 & 20.72 & 0.06 & 34.56 & 0.00 & 4.7 & 1.2 & 0.06 & 0.01 & 4.2 & 0.2 & 0.525 & 0.092 \\
\hline 9 & 123.898 & 26.830 & 128 & 12.3 & 0.08 & 57 & 39 & 21.90 & 0.01 & 34.49 & 0.00 & 2.5 & 0.7 & 0.02 & 0.01 & 3.5 & 0.0 & 0.689 & 0.032 \\
\hline 10 & 124.586 & 26.586 & 154 & 12.3 & 0.08 & 56 & 35 & 23.25 & 0.00 & 34.36 & 0.00 & 1.9 & 0.2 & 0.04 & 0.08 & 2.6 & 0.2 & 0.762 & 0.022 \\
\hline 11 & 125.354 & 26.292 & 1258 & 12.3 & 0.10 & 46 & 124 & 24.24 & 0.14 & 34.39 & 0.01 & 2.1 & 0.6 & 0.01 & 0.02 & 2.3 & 0.3 & 0.394 & 0.028 \\
\hline $12 \mathrm{~A}$ & 125.899 & 27.234 & 237 & 20.5 & 0.12 & 40 & 19 & 23.65 & 0.01 & 34.43 & 0.03 & 1.4 & 0.4 & 0.00 & 0.00 & 2.6 & 0.1 & 0.555 & 0.020 \\
\hline 13 & 126.439 & 28.127 & 146 & 20.5 & 0.06 & 79 & 71 & 22.86 & 0.01 & 34.54 & 0.00 & 1.1 & 0.1 & 0.03 & 0.06 & 2.9 & 0.4 & 0.430 & 0.262 \\
\hline 14 & 125.667 & 28.418 & 106 & 20.5 & 0.07 & 65 & 16 & 20.27 & 0.02 & 34.52 & 0.04 & 1.3 & 0.6 & 0.01 & 0.01 & 2.9 & 0.2 & 0.948 & 0.051 \\
\hline 15 & 124.898 & 28.708 & 96 & 20.5 & 0.12 & 40 & 85 & 18.37 & 0.01 & 34.47 & 0.00 & 4.0 & 1.1 & 0.15 & 0.03 & 7.3 & 2.4 & 0.255 & 0.026 \\
\hline 16 & 124.123 & 29.001 & 69 & 32.9 & 0.15 & 32 & 61 & 17.81 & 0.01 & 34.38 & 0.00 & 3.1 & 0.1 & 0.15 & 0.01 & 7.0 & 0.1 & 0.501 & 0.034 \\
\hline 17 & 123.350 & 29.295 & 71 & 32.9 & 0.17 & 27 & 61 & 16.81 & 0.02 & 34.46 & 0.00 & 4.6 & 1.7 & 0.24 & 0.03 & 9.3 & 0.5 & 0.435 & 0.038 \\
\hline 18 & 122.666 & 29.552 & 46 & 32.9 & 0.33 & 14 & 21 & 14.67 & 0.11 & 33.24 & 0.06 & 9.5 & 4.6 & 0.46 & 0.04 & 16.7 & 0.4 & 0.876 & 0.095 \\
\hline 29 & 123.246 & 30.461 & 59 & 16.1 & 0.26 & 18 & 55 & 16.29 & 0.01 & 34.38 & 0.00 & 4.3 & 0.4 & 0.28 & 0.07 & 9.1 & 0.2 & 0.627 & 0.052 \\
\hline 19 & 123.149 & 31.626 & 37 & 16.1 & 0.41 & 11 & 11 & 12.13 & 0.01 & 31.98 & 0.07 & 14.6 & 1.9 & 0.51 & 0.05 & 20.7 & 0.2 & 0.692 & 0.071 \\
\hline 20 & 123.917 & 31.334 & 52 & 16.1 & 0.27 & 17 & 17 & 13.76 & 0.07 & 33.61 & 0.06 & 6.3 & 2.9 & 0.51 & 0.04 & 15.9 & 1.4 & 0.805 & 0.125 \\
\hline 21 & 124.690 & 31.040 & 53 & 35.3 & 0.26 & 18 & 51 & 14.42 & 0.01 & 33.86 & 0.11 & 10.6 & 3.7 & 0.53 & 0.14 & 13.1 & 2.0 & 0.465 & 0.225 \\
\hline 22 & 125.446 & 30.729 & 63 & 35.3 & 0.22 & 21 & 33 & 15.95 & 0.13 & 33.73 & 0.03 & 6.2 & 2.8 & 0.33 & 0.02 & 11.8 & 0.2 & 0.913 & 0.207 \\
\hline 23 & 126.229 & 30.458 & 80 & 35.3 & 0.17 & 28 & 75 & 16.73 & 0.06 & 33.96 & 0.03 & 6.8 & 0.7 & 0.35 & 0.02 & 12.4 & 0.3 & 0.645 & 0.068 \\
\hline 24 & 127.002 & 30.166 & 102 & 35.3 & 0.14 & 34 & 100 & 18.46 & 0.12 & 34.31 & 0.03 & 4.1 & 0.6 & 0.22 & 0.05 & 8.7 & 0.1 & 0.603 & 0.078 \\
\hline
\end{tabular}

Note: $B D$ is the depth of sea bed, $\sigma$ is the standard deviation of the mean. 


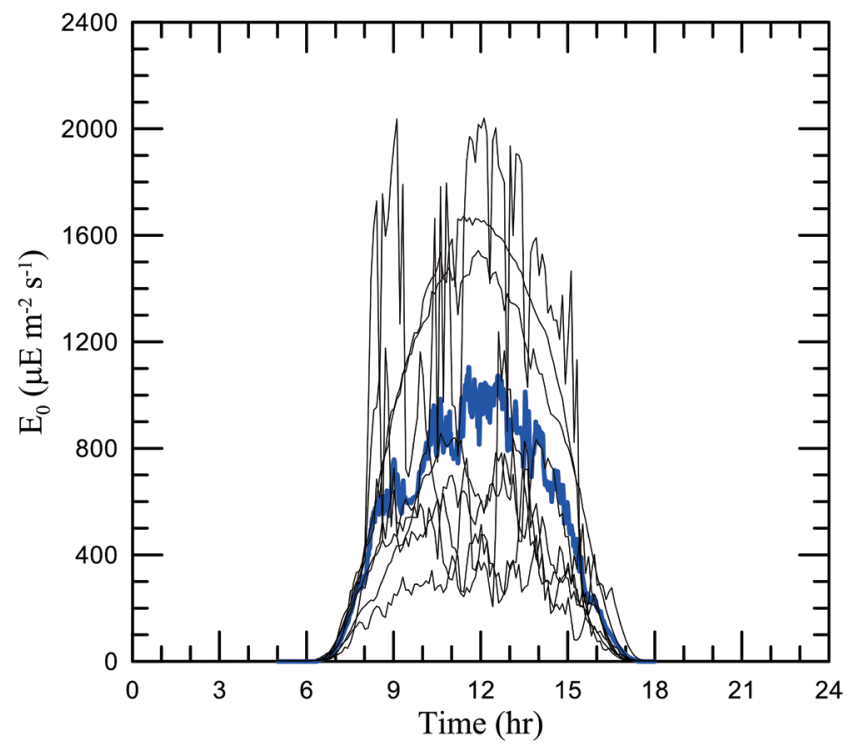

Fig. 2. Time variation of on-deck irradiance during the expedition (2 - 11 January 2008). The blue line is the average irradiance over the whole sampling period. (Color online only)

(a)

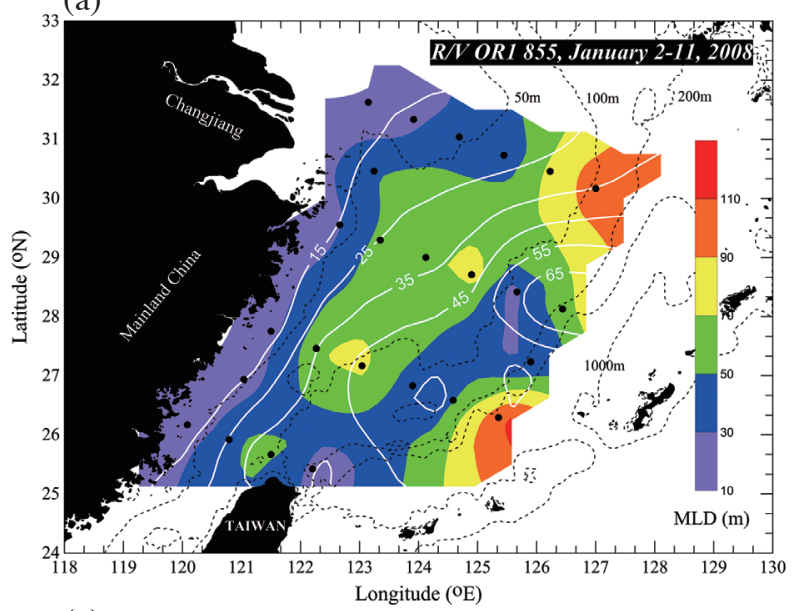

(c)

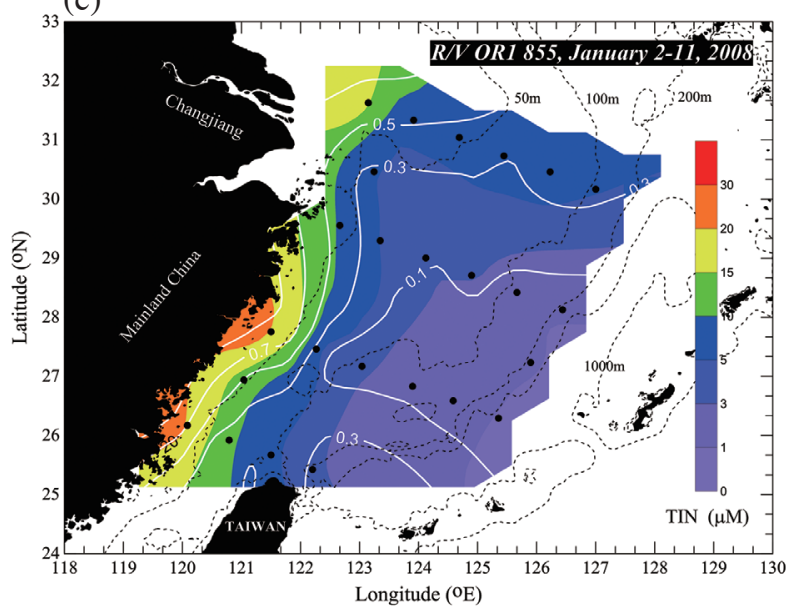

(b)

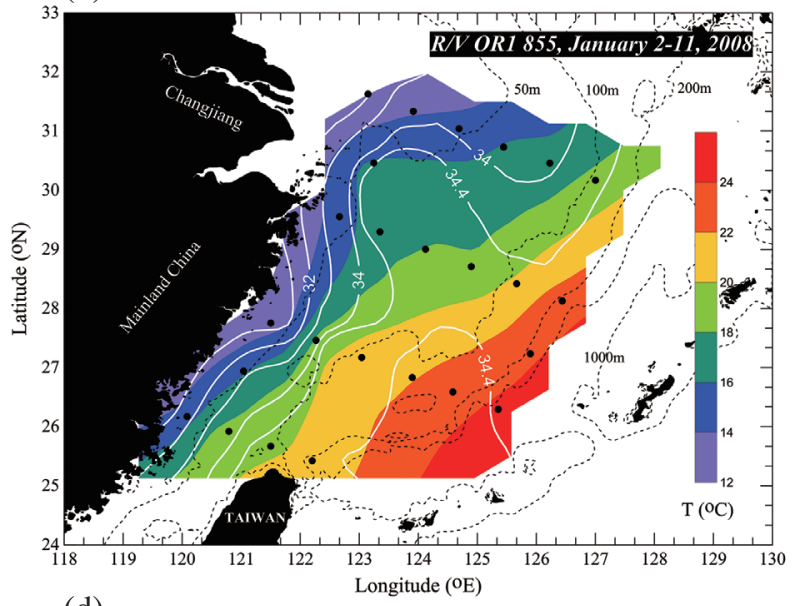

(d)

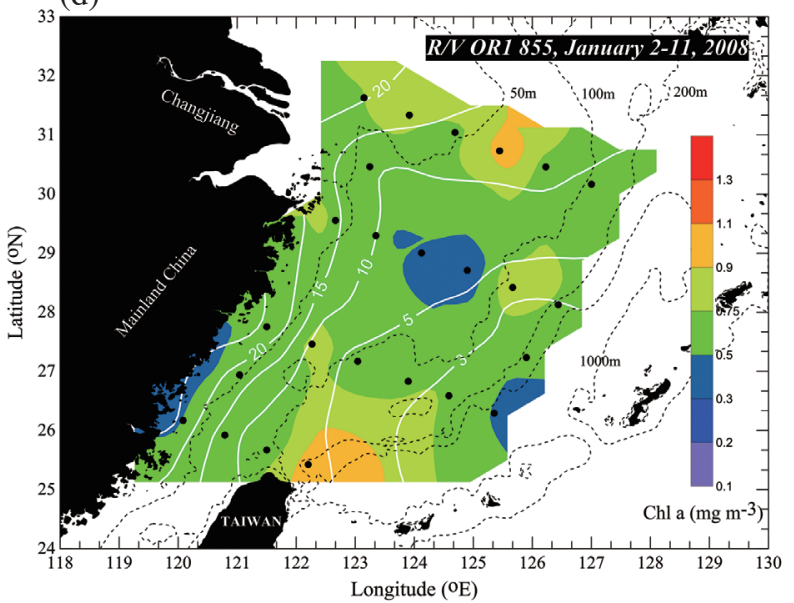

Fig. 3. (a) Spatial distribution of euphotic depth (white lines) and mixed layer depth (MLD). (b) Mean temperature and salinity (white lines) in the MLD. (c) Total inorganic nitrogen and phosphate concentrations (white lines). (d) Chlorophyll $a$ and silicate concentrations (white lines). 
Table 2. Photosynthetic parameters of the $\mathrm{P}^{\mathrm{B}}$-E curves in different depth at each station and euphotic zone integrated primary production (IP).

\begin{tabular}{|c|c|c|c|c|c|c|c|c|c|c|c|c|c|c|}
\hline \multirow{2}{*}{$\begin{array}{c}\text { Station } \\
\text { no. }\end{array}$} & \multirow{2}{*}{ Lon $\left({ }^{\circ} \mathbf{E}\right)$} & \multirow{2}{*}{ Lat $\left({ }^{\circ} \mathbf{N}\right)$} & \multicolumn{5}{|c|}{ Local Time } & \multirow{2}{*}{$\begin{array}{l}\mathrm{Ze} \\
(\mathrm{m})\end{array}$} & \multirow{2}{*}{$\begin{array}{c}\text { MLD } \\
(\mathrm{m})\end{array}$} & \multicolumn{2}{|c|}{ Depth (m) } & \multirow{2}{*}{$P_{m}^{B}$} & \multirow{2}{*}{$\alpha$} & \multirow{2}{*}{ 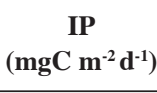 } \\
\hline & & & уyуy & $\mathbf{m m}$ & dd & hr & $\min$ & & & Bottom & Sampling & & & \\
\hline \multirow[t]{3}{*}{3} & 120.7910 & 25.9187 & 2008 & 1 & 3 & 12 & 35 & 25 & 40 & 76 & 0 & 2.75 & 0.010 & 139 \\
\hline & & & & & & & & & & & 11 & 2.74 & 0.007 & \\
\hline & & & & & & & & & & & 60 & 2.32 & 0.010 & \\
\hline \multirow[t]{3}{*}{6} & 121.5005 & 27.7518 & 2008 & 1 & 4 & 12 & 14 & 8 & 19 & 30 & 0 & 3.16 & 0.012 & 54 \\
\hline & & & & & & & & & & & 10 & 2.73 & 0.008 & \\
\hline & & & & & & & & & & & 20 & 3.14 & 0.010 & \\
\hline \multirow[t]{3}{*}{10} & 124.5813 & 26.5833 & 2008 & 1 & 5 & 12 & 51 & 56 & 35 & 154 & 0 & 2.94 & 0.010 & 320 \\
\hline & & & & & & & & & & & 25 & 2.90 & 0.008 & \\
\hline & & & & & & & & & & & 51 & 5.84 & 0.015 & \\
\hline \multirow[t]{3}{*}{13} & 126.4392 & 28.1267 & 2008 & 1 & 6 & 10 & 40 & 79 & 71 & 146 & 0 & 2.44 & 0.012 & 327 \\
\hline & & & & & & & & & & & 26 & 3.03 & 0.009 & \\
\hline & & & & & & & & & & & 51 & 1.91 & 0.009 & \\
\hline \multirow[t]{3}{*}{16} & 124.1295 & 28.9992 & 2008 & 1 & 7 & 12 & 56 & 32 & 61 & 69 & 0 & 2.82 & 0.010 & 138 \\
\hline & & & & & & & & & & & 20 & 2.87 & 0.011 & \\
\hline & & & & & & & & & & & 41 & 2.57 & 0.011 & \\
\hline \multirow[t]{3}{*}{29} & 123.2464 & 30.4606 & 2008 & 1 & 8 & 6 & 8 & 18 & 55 & 59 & 0 & 3.60 & 0.012 & 111 \\
\hline & & & & & & & & & & & 21 & 3.03 & 0.009 & \\
\hline & & & & & & & & & & & 40 & 3.53 & 0.010 & \\
\hline \multirow[t]{3}{*}{19} & 123.1488 & 31.6263 & 2008 & 1 & 8 & 14 & 41 & 11 & 11 & 37 & 0 & 2.21 & 0.006 & 47 \\
\hline & & & & & & & & & & & 10 & 2.37 & 0.009 & \\
\hline & & & & & & & & & & & 20 & 2.90 & 0.010 & \\
\hline \multirow[t]{3}{*}{23} & 126.2288 & 30.4578 & 2008 & 1 & 9 & 10 & 57 & 28 & 75 & 80 & 0 & 3.90 & 0.010 & 191 \\
\hline & & & & & & & & & & & 26 & 3.43 & 0.010 & \\
\hline & & & & & & & & & & & 41 & 3.09 & 0.009 & \\
\hline \multirow[t]{3}{*}{24} & 127.0022 & 30.1658 & 2008 & 1 & 9 & 15 & 20 & 34 & 102 & 102 & 0 & 2.70 & 0.008 & 166 \\
\hline & & & & & & & & & & & 25 & 2.38 & 0.010 & \\
\hline & & & & & & & & & & & 51 & 1.05 & 0.003 & \\
\hline
\end{tabular}

Note: The unit of $P_{m}^{B}$ and $\alpha$ are $g C(g C h l)^{-1} h^{-1}$ and $g C(g C h l)^{-1} h^{-1}\left(\mu E m^{-2} s^{-1}\right)^{-1}$, respectively. 


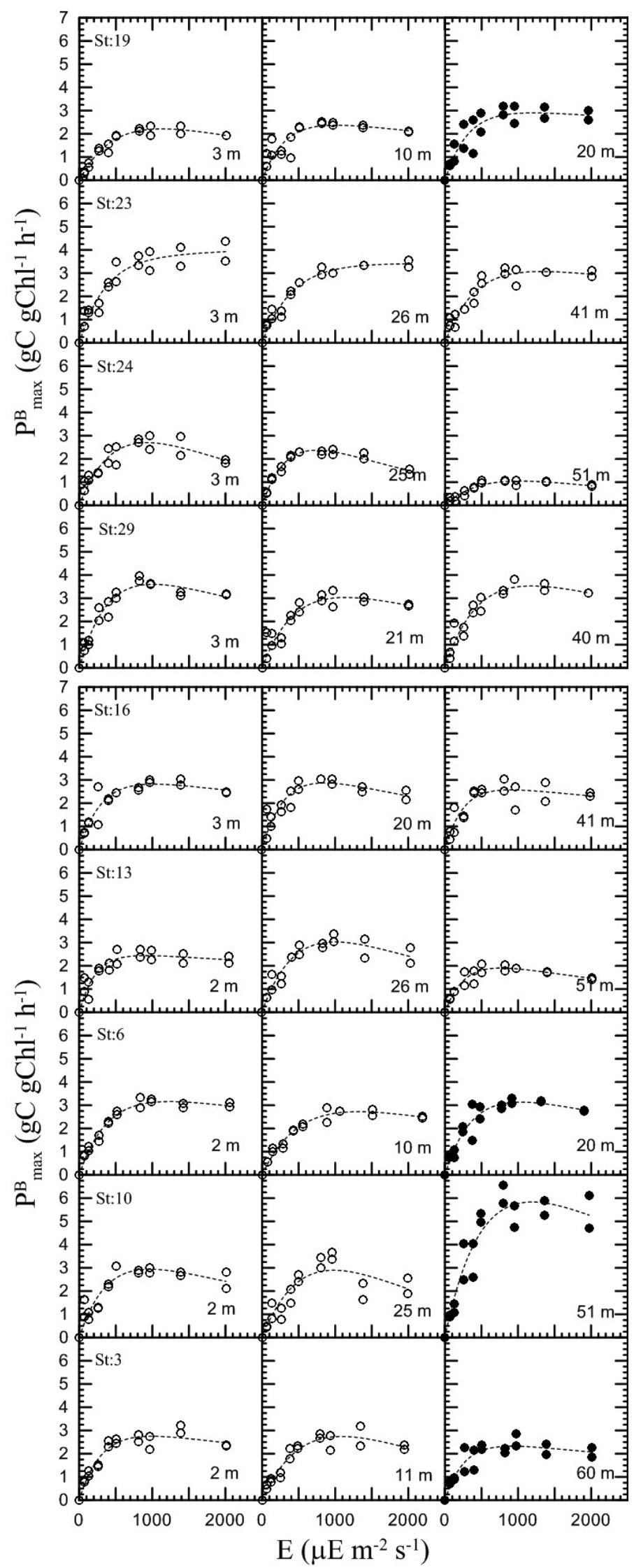

Fig. 4. Regression analyses of $\mathrm{P}^{\mathrm{B}}$-E curve results (dashed line) with Eq. (2) for the different depths of the sampling stations (from north to south) where on-board incubation experiments were conducted. Filled circles are the results for depths greater than the mixed layer depths. 
IP ranged between 47 and $327 \mathrm{mgC} \mathrm{m} \mathrm{m}^{-2} \mathrm{~d}^{-1}$. IP increased southeastwardly toward the open sea with higher values of IP found at the stations near the shelf break (station 10 and 13 in Table 2 and Fig. 1).

\section{DISCUSSION}

\subsection{Effect of Temperature and Nutrient on $\boldsymbol{P}_{m}^{B}$}

Temperature and nutrient availability were usually considered to be the major controlling factors in the phytoplankton growth and primary production. Photochemical processes themselves such as light absorption and transfer of excitation energy are essentially temperature independent. However, other photosynthesis related processes such as carbon dioxide fixation and enzyme activities are temperature dependent (Raven and Geider 1988). Therefore, the temperature effect on photosynthetic parameters in the world's ocean showed inconsistent dependency. $P_{m}^{B}$ is often described as a function of temperature (Eppley 1972; Côté and Platt 1983; Behrenfeld and Falkowski 1997). However, $P_{m}^{B}$ to temperature exhibited a hyperbolic response, with an initial linear increase at lower temperature and reaching to a plateau at higher temperature, has been observed in the polar and temperate areas (Li et al. 1984; Smith Jr. and Donaldson 2015; Xie et al. 2015). The complicated relationship between the temperature and $P_{m}^{B}$ was considered due to the combination of specific photosynthetic responses to temperature. In this study, even temperature showed a strong spatial gradient $\left(12-24^{\circ} \mathrm{C}\right.$; Fig. $\left.3 \mathrm{~b}\right), P_{m}^{B}$ was found no significant correlation to temperature (p $>0.05$; Fig. 5). It indicated that $P_{m}^{B}$ might be located on the plateau phase (optimum temperature) in our study area. To the least extent, temperature was not the controlling factor of $P_{m}^{B}$ in the winter of the subtropical ECS.

The phytoplankton photosynthesis and growth depend on nutrients. Chlorophyll-normalized primary production $\left(\mathrm{P}^{\mathrm{B}}\right)$ has been observed as a function of nutrients in the equatorial Pacific Ocean (Barber and Chavez 1991). However, $\mathrm{P}^{\mathrm{B}}$ can remain high despite nutrient limitation through regulating cellular carbon to chlorophyll ratio (Cullen et al. 1992). It would be difficult to evaluate the nutrient effect on photosynthetic parameters without $\mathrm{C}$ : $\mathrm{Chl}$ ratios. In field observations, $P_{m}^{B}$ has been reported to be not correlated to nutrient in the polar and temperate regions (Smith Jr. and Donaldson 2015; Xie et al. 2015). In this study, like temperature, total inorganic nitrogen showed a strong gradient from the coast to the open ocean ( 25 to $1 \mu \mathrm{M}$; Fig. 3c). However, we also observed that $P_{m}^{B}$ was not correlated to nutrient (Fig. 5). Moreover, differential inhibition by environmental factors may regulate photosynthetic parameters in different magnitude. For instance, low temperature and high turbidity may inhibit photosynthetic parameters in the inner-shelf area in spite of high nutrient supply. On the other hand, in the warm and clear outer-shelf waters, photosyn- thetic parameters might be inhibited by the scarcity of nutrient supply. The differential inhibition could be caused by physical or chemical factors or both.

We concluded that, altering environmental factors such as temperature and nutrients will not affect the behavior of photosynthetic parameters in the winter of the ECS.

\subsection{Mixing Control of Photosynthetic Parameters}

Photoadaptation of phytoplankton in response to light availability was another controlling factor on how single species phytoplankton influences the variation of $\mathrm{P}^{\mathrm{B}}-\mathrm{E}$ curve parameters. In general, $P_{m}^{B}$ increases with increasing irradiance whereas variability in $\alpha$ is less predictable (Cullen et al. 1992; Jumars 1993; Gong et al. 1999). In winter, when the water was isothermal and well-mixed below the euphotic zone, phytoplankton within the mixed layer behaved similar (Ryther and Menzel 1959; Falkowski 1981). Figure 6 showed the relationship between percentage of underwater PAR at each station and the percentage of $P_{m}^{B}$ and $\alpha$ relative to its surface value. The $\mathrm{P}^{\mathrm{B}}$-E curve parameters did not show significant differences to the surface values in the euphotic zone, but lower than the surface values were found at depth below $1 \%$ of surface light penetration. The deeper part of the euphotic zone with low light availability showed $\mathrm{P}^{\mathrm{B}}$-E curve parameters similar to those of the surface water with high light availability. Strong vertical mixing of water during winter might have been caused by high atmospheric pressure and strong northeasterly monsoon. The water in the euphotic zone was well-mixed and would have influenced the growth of phytoplankton when the growth of phytoplankton is not well adapted to the light availability at depth, possibly explaining the reason why the $\mathrm{P}^{\mathrm{B}}-\mathrm{E}$ curve parameters did not show distinctive increases in the depth where high intensity of light was available. In general, light-dependency of $\mathrm{P}^{\mathrm{B}}$-E curve parameters was not observed within the euphotic zone at any of the incubation stations. Moreover, with MLD was deeper than the euphotic zone in the entire ECS, phytoplankton in the euphotic zone may encounter similar light exposure and caused a narrow range of photosynthetic parameters. The average and mean of $P_{m}^{B}$ and $\alpha$ within the euphotic zone of the nine incubation stations were $2.82 \pm 0.50 \mathrm{gC}(\mathrm{gChl})^{-1} \mathrm{~h}^{-1}$ and $0.010 \pm$ $0.002 \mathrm{gC}(\mathrm{gChl})^{-1} \mathrm{~h}^{-1}\left(\mu \mathrm{E} \mathrm{m}^{-2} \mathrm{~s}^{-1}\right)^{-1}$ except the outliers where euphotic depths were deeper than MLD at station 10. The mean of $P_{m}^{B}$ in this study was found to be consistent with the mean of optimal specific productivity $\left(P_{m}^{B}\right)$ previously reported for the same survey area by Gong and Liu (2003). The mean of $P_{m}^{B}$ in this study also fall into the range of coastal water $P_{m}^{B}$ in winter $\left(3.0 \pm 1.2 \mathrm{gC} \mathrm{gChl}^{-1} \mathrm{~h}^{-1}\right)$ as reported in Sathyendranath et al. (1995). However, the mean value of $\alpha$ in our study was much lower than their findings $\left[0.026 \pm 0.022 \mathrm{gC}(\mathrm{gChl})^{-1} \mathrm{~h}^{-1}\left(\mu \mathrm{E} \mathrm{m}^{-2} \mathrm{~s}^{-1}\right)^{-1}\right]$. With relatively low solar radiation in the winter, strong mixing could 
further deteriorate light conditions and led low photosynthetic parameters. We proposed that mixing could be a potential controlling mechanism for the spatial homogeneity in the winter of the ECS.

\subsection{Estimation of Euphotic Zone Integrated Primary Production for the Entire ECS}

The mean of $P_{m}^{B}$ and $\alpha$ within the euphotic zone for all incubation stations were $2.82 \pm 0.50 \mathrm{gC}(\mathrm{gChl})^{-1} \mathrm{~h}^{-1}$ and $0.010 \pm 0.002 \mathrm{gC}(\mathrm{gChl})^{-1} \mathrm{~h}^{-1}\left(\mu \mathrm{E} \mathrm{m}^{-2} \mathrm{~s}^{-1}\right)^{-1}$, respectively, showing a small degree of spatial variation. Therefore, we substituted the mean of $P_{m}^{B}$ and $\alpha$ into Eqs. (3a) and (4) to obtain IP of each station and, then compared the results to the IP of each station calculated with the $P_{m}^{B}$ and $\alpha$ obtained from that station (open circles, Fig. 7). Both results were in good agreement with $\mathrm{R}^{2}=0.972$ and RMS (root mean square) error of $16 \mathrm{mgC} \mathrm{m}^{-2} \mathrm{~d}^{-1}$. It was the first observation that the integrated primary production could be estimated using one set of photosynthetic parameters $\left(P_{m}^{B}\right.$ and $\left.\alpha\right)$. However, further investigation is needed to identify if the estimation equation is universal in the winter of the ECS. In addition, we further used sea surface $\mathrm{Chl} a$ concentration to replace depth profile of chlorophyll concentration [Chl (z)] in Eq. (3a) and recalculated IP for each station. The results were compared to the IP of each station calculated with the $P_{m}^{B}$ and $\alpha$ of that station (cross symbols, Fig. 7). We found good correlation between these two values with $\mathrm{R}^{2}=0.968$ and a slightly higher RMS error of $24 \mathrm{mgC} \mathrm{m}^{-2} \mathrm{~d}^{-1}$.

During winter season when strong vertical mixing is present, we can estimate primary production for all other stations within the study area by integrating the mean value of $\mathrm{P}^{\mathrm{B}}$-E curve parameters into Eqs. (3a) and (4). Consequently, euphotic zone integrated primary production can be obtained for the whole area without carrying out incubation experiments. Applying this approach, we found the euphotic zone integrated primary production to vary between 49 and 522 $\mathrm{mgC} \mathrm{m} \mathrm{d}^{-2}$ in the entire ECS. Spatial distribution of euphotic zone integrated primary production for the entire study area is shown in Fig. 8a. For water depths shallower than 200 m, primary production showed an increasing trend towards the southeastern shelf waters. The highest value was found between 100 and $200 \mathrm{~m}$ shelf break area (Fig. 8a). The average primary production was $67 \pm 34 \mathrm{mgC} \mathrm{m}^{-2} \mathrm{~d}^{-1}$ for coastal area ( $<50 \mathrm{~m}$ isobath), $142 \pm 68 \mathrm{mgC} \mathrm{m}^{-2} \mathrm{~d}^{-1}$ at the middle shelf area (50 - $100 \mathrm{~m}$ isobath), and $308 \pm 114 \mathrm{mgC} \mathrm{m}^{-2} \mathrm{~d}^{-1}$ at the edge of continental shelf (100 - $200 \mathrm{~m}$ isobath). The spatial average value of primary production for the whole ECS shelf was $186 \pm 117 \mathrm{mgC} \mathrm{m}^{-2} \mathrm{~d}^{-1}$.

\subsection{Comparison Between Field-Observed and Satellite-Derived Primary Production}

Standard products of satellite-derived ocean color pri- mary production is the most popular data used to study marine biogeochemical cycling and long-term change under the forcing of global change, but the quality of the products relies on the accuracy of ocean color derived near surface chlorophyll concentration and primary production algorithm. Generally, it is acceptable to apply standard products of satellite-derived primary production for research in the open ocean. However, application of such standard products in regional studies is still questionable, especially when the shelf sea areas are dominated by large rivers where huge amount of suspended particles and color dissolved organic matters were present (e.g., Gong 2004; Gong et al. 2007). Aside from this, it should be mentioned that useful daily satellite images are scarce because of high degree cloud coverage due to the bad weather condition in the monsoon area especially during the winter. For example, more than $90 \%$ of the present study area was covered by cloud every day in the period of our field investigation (http://oceancolor.gsfc. nasa.gov). The monthly average product mentioned on the website should be thus examined carefully. We compared our results with the monthly average satellite-derived primary production for the same period in January 2008 and
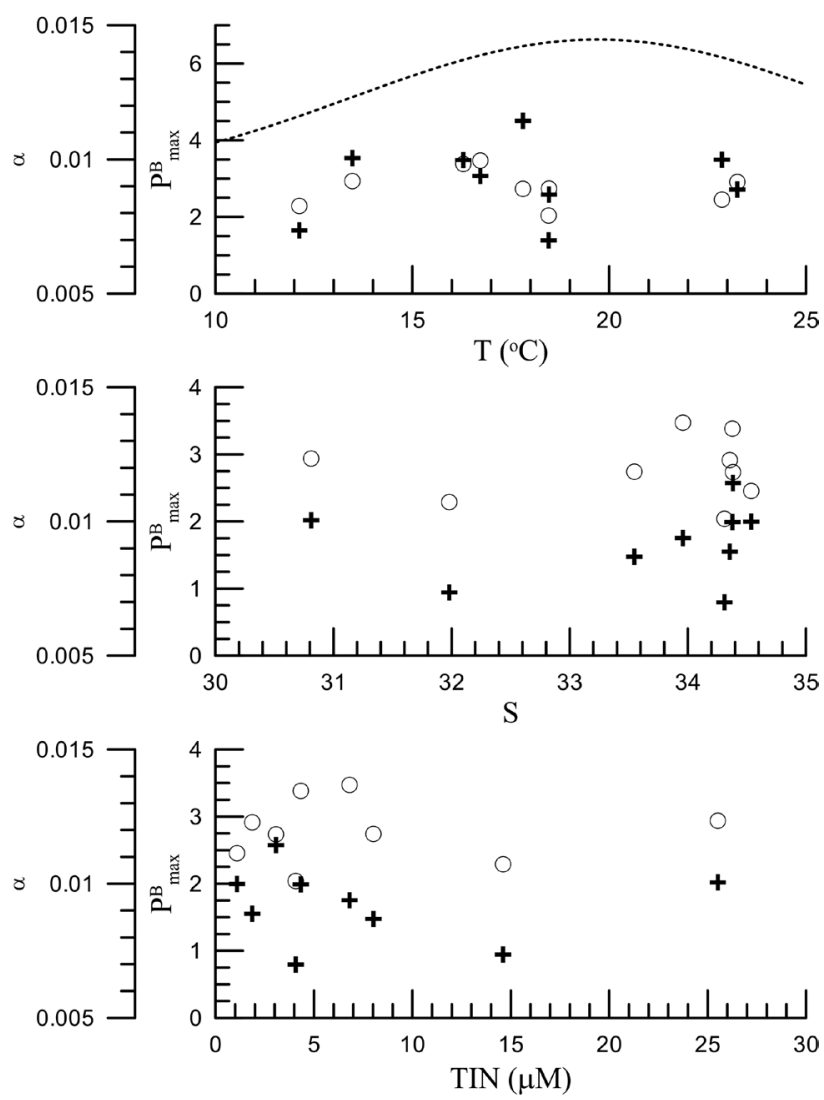

Fig. 5. Relationship between average $\mathrm{P}^{\mathrm{B}}-\mathrm{E}$ curve parameters and seawater temperature, salinity, and nutrients of the MLD where primary productivity experiments were conducted. Open circles and crosses represent $P_{m}^{B}$ and $\alpha$, respectively. The dashed line shows the global average $P_{\text {opt }}^{B}$ adopted from Behrenfeld and Falkowski (1997). 


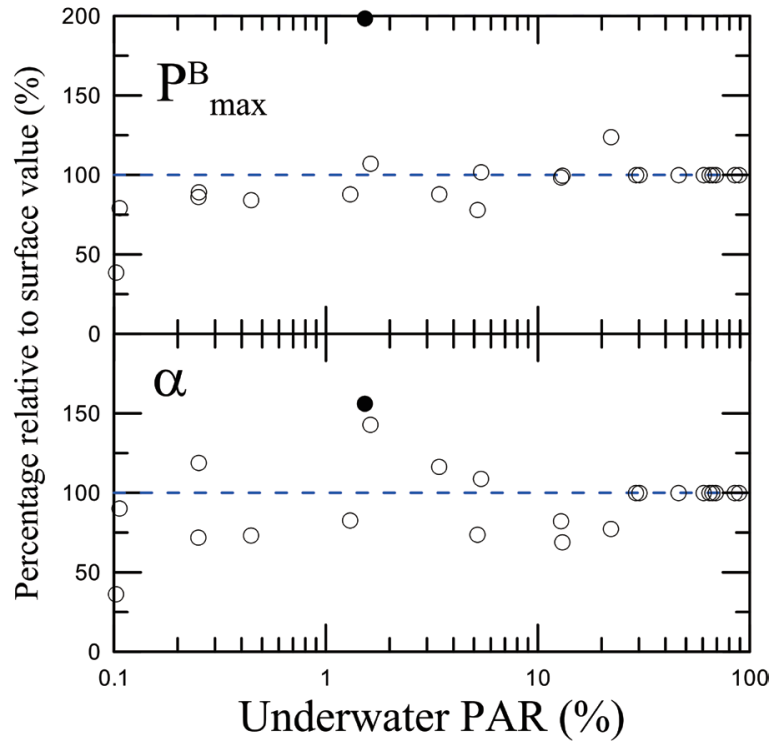

Fig. 6. Relationship of $\mathrm{P}^{\mathrm{B}}-\mathrm{E}$ curve parameters $\left(P_{m}^{B}\right.$ and $\left.\alpha\right)$ to underwater PAR and the percentage relative to surface value of each depth below surface layer (open circles). Filled circles show data within euphotic layer but below mixed layer depth (51 $\mathrm{m}$ at station 10). (Color online only)

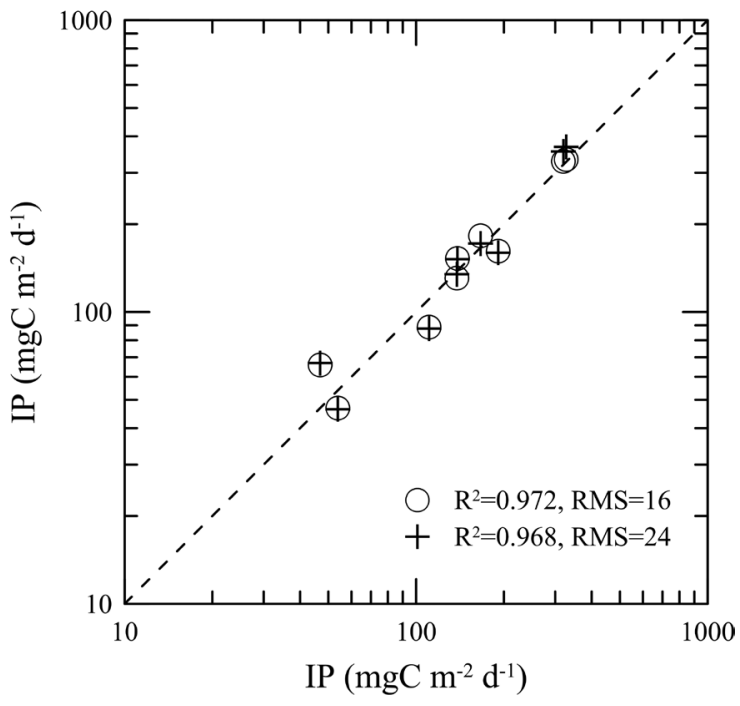

Fig. 7. Relationship between integrated primary production of each station (X-Axis) and the integrated primary production calculated with the average values of $\mathrm{P}^{\mathrm{B}}$-E curve parameters, both calculated with Eqs. (2b) and (3) (open circles). Similar values were found when depthdependent chlorophyll $a$ concentrations in Eq. (3) were replaced by the surface chlorophyll $a$ concentrations (cross). Both p-values were $<0.05$. (a)

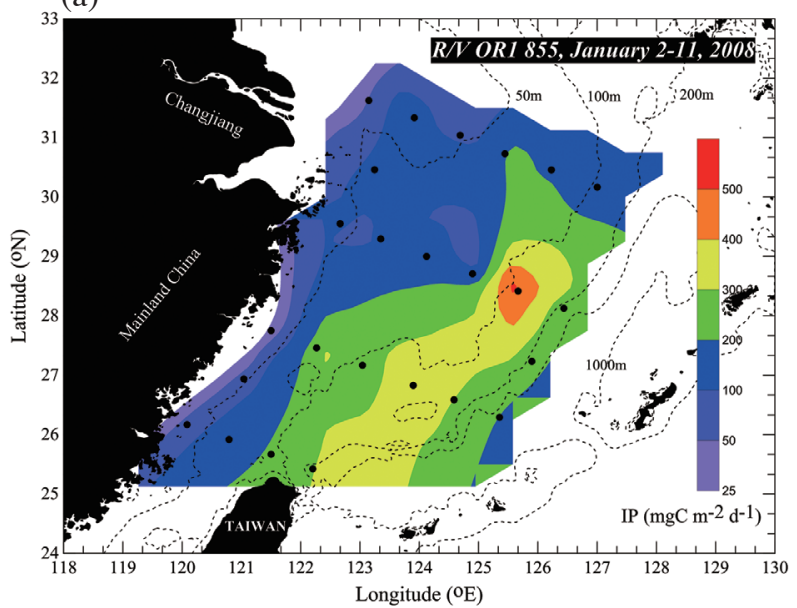

(b)

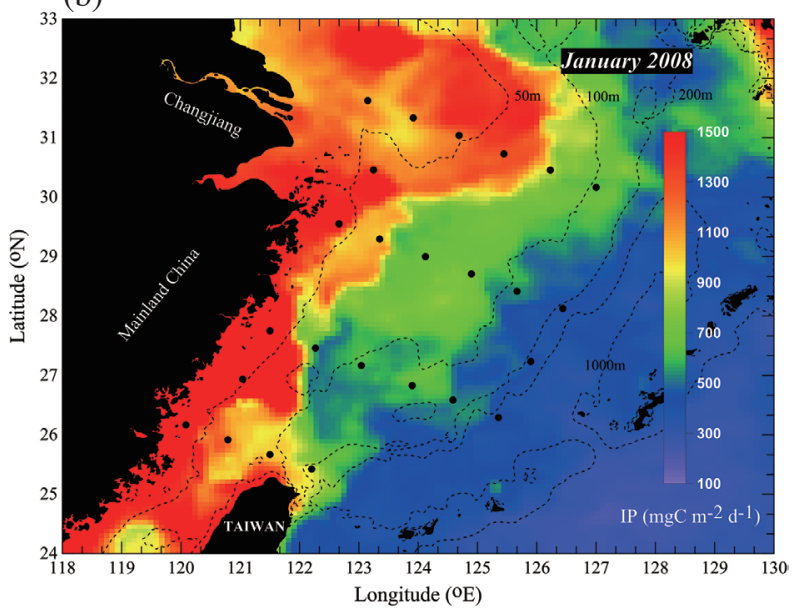

Fig. 8. (a) Spatial distribution of primary productivity in the euphotic zone after applying average values of $\mathrm{P}^{\mathrm{B}}$-E curve parameters in Eqs. (2b) and (3). (b) Standard product of satellite-derived monthly primary production for January 2008. Note the scales of primary productivity in (a) and (b) were different.

we found much higher values from the satellite-derived primary production (Fig. 8b) than our estimations (Fig. 8a). Additionally, the satellite-derived IP showed a decreasing trend towards the open sea, which is completely the opposite of the spatial distribution patterns that we found in our field observations. It was evident that field oceanographic investigations are essential especially during the winter. Often, estimation errors of satellite-derived primary production were made by incorrect application of ocean color chlorophyll algorithms and inaccurate primary production data.
The overestimation of satellite-derived primary production was, thus, partly caused by the overestimation of global average optimal photosynthetic rate used in the primary production algorithm (see dashed line in top panel of Fig. 5).

\section{CONCLUSION}

Phytoplankton photosynthesis-irradiance relationships ( $\mathrm{P}^{\mathrm{B}}$-E curve) and environmental conditions (hydrography, nutrients, and $\mathrm{Chl} a$ concentrations) in the subtropical East 
China Sea were investigated during a rough winter season. Due to the strong vertical mixing of seawater, the depth of euphotic zone was shallower than the mixed layer depth and caused indistinct changes of $\mathrm{P}^{\mathrm{B}}-\mathrm{E}$ curve parameters $\left(P_{m}^{B}\right.$ and $\alpha)$ in the euphotic zone. The results of $\mathrm{P}^{\mathrm{B}}$-E curve parameters analyses from the on-board incubation experiments did not show significant depth or spatial distribution variations and the means of $P_{m}^{B}$ and $\alpha$ were $2.82 \pm 0.50 \mathrm{gC}(\mathrm{gChl})^{-1} \mathrm{~h}^{-1}$ and $0.010 \pm 0.002 \mathrm{gC}(\mathrm{gChl})^{-1} \mathrm{~h}^{-1}\left(\mu \mathrm{E} \mathrm{m}^{-2} \mathrm{~s}^{-1}\right)^{-1}$, respectively. The strong winter mixing and/or differential inhibitions caused the spatial homogeneity of photosynthetic parameters. The euphotic zone integrated primary production calculated from the mean $P_{m}^{B}$ and $\alpha$ along with the depth profiles of chlorophyll concentration were consistent with the values of $P_{m}^{B}$ and $\alpha$ obtained from each station separately $\left(\mathrm{R}^{2}=0.972\right.$, RMS $\left.=16 \mathrm{mgC} \mathrm{m}^{-2} \mathrm{~d}^{-1}\right)$. The euphotic zone integrated primary production for the entire East China Sea was then estimated based on above suggestion and we found increasing trend from the northwestern part of the shelf near Changjiang towards southeast to the shelf break region. The value of primary production ranged from $49-522 \mathrm{mgC} \mathrm{m}^{-2} \mathrm{~d}^{-1}$ with the shelf-averaged value being $186 \pm 117 \mathrm{mgC} \mathrm{m}^{-2} \mathrm{~d}^{-1}$. Compared with the findings of our field study, the standard product of satellite-derived IP is not only overestimated; it also shows entirely opposite spatial distribution patterns. The euphotic zone integrated primary production calculated from the averaged $P_{m}^{B}, \alpha$, and sea surface chlorophyll concentrations was consistent with that calculated with the $P_{m}^{B}$ and $\alpha$ obtained from each station separately $\left(\mathrm{R}^{2}=0.968\right.$, RMS $\left.=24 \mathrm{mgC} \mathrm{m}^{-2} \mathrm{~d}^{-1}\right)$. Thus, the euphotic zone integrated primary production in the continental shelf of the ECS in winter can be estimated by the following equation:

$I P=\int_{0}^{Z_{e}} \int_{0}^{t} C_{S} P_{m}^{B}\left[1-e^{-\frac{\alpha E(z, t)}{P_{m}^{B}}}\right] d t d z$

where $C_{S}$ is the sea surface $\mathrm{Chl} a$ concentration, $P_{m}^{B}=2.82$ $\mathrm{gC}(\mathrm{gChl})^{-1} \mathrm{~h}^{-1}$ and $\alpha=0.010 \mathrm{gC}(\mathrm{gChl})^{-1} \mathrm{~h}^{-1}\left(\mu \mathrm{E} \mathrm{m}^{-2} \mathrm{~s}^{-1}\right)^{-1}$.

Acknowledgements We are grateful to the chief scientist Prof. Wen-Chen Chou, and the captain, crew and scientific party of the R/V Ocean Researcher I for their assistance with data acquisition. This work was funded by the Ministry of Science and Technology of Taiwan, Republic of China.

\section{REFERENCES}

Barber, R. T. and F. P. Chavez, 1991: Regulation of primary productivity rate in the equatorial Pacific Ocean. Limnol. Oceanogr., 36, 1803-1815, doi: 10.4319/ lo.1991.36.8.1803. [Link]

Beardsley, R. C., R. Limebumer, H. Yu, and G. A. Cannon, 1985: Discharge of the Changjiang (Yangtze River) into the East China Sea. Cont. Shelf Res., 4, 57-76, doi: 10.1016/0278-4343(85)90022-6. [Link]

Behrenfeld, M. J. and P. G. Falkowski, 1997: Photosynthetic rates derived from satellite-based chlorophyll concentration. Limnol. Oceanogr., 42, 1-20, doi: 10.4319/ lo.1997.42.1.0001. [Link]

Cai, W. J., X. Hu, W. J. Huang, M. C. Murell, J. C. Lehrter, S. E. Lohrenz, W. C. Chou, W. Zhai, J. T. Hollibaugh, Y. Wang, P. Zhao, X. Guo, K. Gundersen, M. Dai, and G. C. Gong, 2011: Acidification of subsurface coastal waters enhanced by eutrophication. Nat. Geosci., 4, 766-770, doi: 10.1038/ngeo1297. [Link]

Chen, C. C., G. C. Gong, and F. K. Shiah, 2007: Hypoxia in the East China Sea: One of the largest coastal low-oxygen areas in the world. Mar. Environ. Res., 64, 399408, doi: 10.1016/j.marenvres.2007.01.007. [Link]

Chen, Y. L. L., H. Y. Chen, G. C. Gong, Y. H. Lin, S. Jan, and M. Takahashi, 2004: Phytoplankton production during a summer coastal upwelling in the East China Sea. Cont. Shelf Res., 24, 1321-133, doi: 10.1016/j. csr.2004.04.002. [Link]

Chou, W. C., G. C. Gong, D. D. Sheu, S. Jan, C. C. Hung, and C. C. Chen, 2009: Reconciling the paradox that the heterotrophic waters of the East China Sea shelf act as a significant $\mathrm{CO}_{2}$ sink during the summertime: Evidence and implications. Geophys. Res. Lett., 36, L15607, doi: 10.1029/2009GL038475. [Link]

Côté, B. and T. Platt, 1983: Day-to-day variations in the spring-summer photosynthetic parameters of coastal marine phytoplankton. Limnol. Oceanogr., 28, 320344, doi: 10.4319/lo.1983.28.2.0320. [Link]

Cullen, J. J., X. Yang, and H. L. MacIntyre, 1992: Nutrient limitation of marine photosynthesis. In: Falkowski, P. G. and A. D. Woodhead (Eds), Primary Productivity and Biogeochemical Cycles in the Sea, Springer, New York, USA, 69-88.

Eppley, R. W., 1972: Temperature and phytoplankton growth in the sea. Fish. Bull., 70, 1063-1085.

Falkowski, P. G., 1981: Light-shade adaptation and assimilation numbers. J. Plankton Res., 3, 203-216, doi: 10.1093/plankt/3.2.203. [Link]

Gong, G. C., 2004: Absorption coefficients of colored dissolved organic matter in the surface waters of the East China Sea. Terr. Atom. Ocean. Sci., 15, 75-87, doi: 10.3319/TAO.2004.15.1.75(O). [Link]

Gong, G. C. and G. J. Liu, 2003: An empirical primary production model for the East China Sea. Cont. Shelf Res., 23, 213-224, doi: 10.1016/S0278-4343(02)00166-8. [Link]

Gong, G. C., K. K. Liu, and S. C. Pai, 1995: Prediction of nitrate concentration from two end member mixing in the southern East China Sea. Cont. Shelf Res., 15, 827842, doi: 10.1016/0278-4343(94)00039-P. [Link]

Gong, G. C., J. Chang, and Y. H. Wen, 1999: Estimation 
of annual primary production in the Kuroshio waters northeast of Taiwan using a photosynthesis-irradiance model. Deep-Sea Res., 46, 93-108, doi: 10.1016/ S0967-0637(98)00057-0. [Link]

Gong, G. C., J. Chang, and M. H. Liang, 2001: A photosynthetic-irradiance model for the upwelling region northeast of Taiwan and its application to the East China Sea. J. Geophys. Res., 106, 19957-19968, doi: 10.1029/1999JC000044. [Link]

Gong, G. C., Y. H. Wen, B. W. Wang, and G. J. Liu, 2003: Seasonal variation of chlorophyll $a$ concentration, primary production and environmental conditions in the subtropical East China Sea. Deep-Sea Res., 50, 12191236, doi: 10.1016/S0967-0645(03)00019-5. [Link]

Gong, G. C., J. Chang, K. P. Chiang, S. W. Duan, and L. A. Codispoti, 2006: Reduction of primary production and changing of nutrient ratio in the East China Sea: Effect of the Three Gorge Dam?. Geophys. Res. Lett., 33, L07610, doi: 10.1029/2006GL025800. [Link]

Gong, G. C., C. C. Hung, and J. Chang, 2007: Reply to comment by Jinchun Yuan et al. on "Reduction of primary production and changing of nutrient ratio in the East China Sea: Effect of the Three Gorge Dam?". Geophys. Res. Lett., 34, L14610, doi: 10.1029/2007GL029633. [Link]

Gong, G. C., K. K. Liu, K. P. Chiang, T. M. Hsiung, J. Chang, C. C. Chen, C. C. Hung, W. C. Chou, C. C. Chung, H. Y. Chen, F. K. Shiah, A. Y. Tsai, C. H. Hsieh, J. C. Shiao, C. M. Tseng, S. C. Hsu, H. J. Lee, M. A. Lee, I. I. Lin, and F. Tsai, 2011: Yangtze River floods enhance coastal ocean phytoplankton biomass and potential fish production. Geophys. Res. Lett., 38, L13603, doi: 10.1029/2011GL047519. [Link]

Jumars, P. A., 1993: Concepts in Biological Oceanography: An Interdisciplinary Primer, Oxford University Press, Oxford, United Kingdom, 368 pp.

Li, W. K. W., J. C. Smith, and T. Platt, 1984: Temperature response of photosynthetic capacity and carboxylase activity in Arctic marine phytoplankton. Mar. Ecol. Prog. Ser., 17, 237-243, doi: 10.3354/meps017237. [Link]

Liu, K. K., S. Y. Chao, H. J. Lee, G. C. Gong, and Y. C. Teng, 2010: Seasonal variation of primary productivity in the East China Sea: A numerical study based on coupled physical-biogeochemical model. Deep-Sea Res. Part II-Top. Stud. Oceanogr., 57, 1762-1782, doi: 10.1016/j.dsr2.2010.04.003. [Link]

Longhurst, A., S. Sathyendranath, T. Platt, and C. Caverhill, 1995: An estimate of global primary production in the ocean from satellite radiometer data. J. Plankton Res., 17, 1245-1271, doi: 10.1093/plankt/17.6.1245. [Link]

Morel, A. and S. Maritorena, 2001: Bio-optical properties of oceanic waters: A reappraisal. J. Geophys. Res., 106, 7163-7180, doi: 10.1029/2000JC000319. [Link]
Nielsen, E. S., 1952: On detrimental effects of high intensities on the photosynthetic mechanism. Physiol. Plant., 5, 334-344, doi: 10.1111/j.1399-3054.1952.tb07529.x. [Link]

Parsons, T. R., Y. Maita, and C. M. Lalli, 1984: A manual of Chemical and Biological Methods for Seawater Analysis, Pergamon Press, New York, 173 pp.

Platt, T. and S. Sathyendranath, 1988: Oceanic primary production: Estimation by remote sensing at local and regional scales. Nature, 241, 1613-1620, doi: 10.1126/ science.241.4873.1613. [Link]

Platt, T. and S. Sathyendranath, 1993: Estimators of primary production for interpretation of remotely sensed data on ocean color. J. Geophys. Res., 98, 14561-14576, doi: 10.1029/93JC01001. [Link]

Platt, T., C. L. Gallegos, and W. G. Harrison, 1980: Photoinhibition of photosynthesis in natural assemblages of marine phytoplankton. J. Mar. Res., 38, 687-701.

Rabouille, C., D. J. Conley, M. H. Dai, W. J. Cai, C. T. A. Chen, B. Lansard, R. Green, K. Yin, P. J. Harrison, M. Dagg, and B. McKee, 2008: Comparison of hypoxia among four river-dominated ocean margins: The Changjiang (Yangtze), Mississippi, Pearl, and Rhône rivers. Cont. Shelf Res., 28, 1527-1537, doi: 10.1016/j. csr.2008.01.020. [Link]

Raven, J. A. and R. J. Geider, 1988: Temperature and algal growth. New Phytol., 110, 441-461, doi: 10.1111/ j.1469-8137.1988.tb00282.x. [Link]

Ryther, J. H. and D. W. Menzel, 1959: Light adaptation by marine phytoplankton. Limnol. Oceanogr., 4, 492-497, doi: 10.4319/lo.1959.4.4.0492. [Link]

Sakshaug, E., A. Bricaud, Y. Dandonneau, P. G. Falkowski, D. A. Kiefer, L. Legendre, A. Morel, J. Parslow, and M. Takahashi, 1997: Parameters of photosynthesis: Definitions, theory and interpretation of results. J. Plankton Res., 19, 1637-1670, doi: 10.1093/plankt/19.11.1637. [Link]

Sathyendranath, S., A. Longhurst, C. M. Caverhill, and T. Platt, 1995: Regionally and seasonally differentiated primary production in the North Atlantic. Deep-Sea Res. Part I-Oceanogr. Res. Pap., 42, 1773-1802, doi: 10.1016/0967-0637(95)00059-F. [Link]

Smith Jr., W. O. and K. Donaldson, 2015: Photosynthesisirradiance responses in the Ross Sea, Antarctica: A meta-analysis. Biogeosciences, 12, 3567-3577, doi: 10.5194/bg-12-3567-2015. [Link]

Trenberth, K. E., P. D. Jones, P. Ambenje, R. Bojariu, D. Easterling, A. Klein Tank, D. Parker, F. Rahimzadeh, J. A. Renwick, M. Rusticucci, B. Soden, and P. Zhai, 2007: Observations: Surface and atmospheric climate change. In: Solomon, S., D. Qin, M. Manning, Z. Chen, M. Marquis, and K. B. Averyt (Eds.), Climate Change 2007: The Physical Science Basis, Contribution of Work Group I to the Fourth Assessment Report 
of the Intergovernmental Panel on Climate Change, Cambridge University Press, Cambridge, United Kingdom, 235-336.

Wang, B., 2006: Cultural eutrophication in the Changjiang (Yangtze River) plume: History and perspective. Estua. Coast. Shelf Sci., 69, 471-477, doi: 10.1016/j. ecss.2006.05.010. [Link]

Wang, B., Q. Wei, J. Chen, and L. Xie, 2012: Annual cycle of hypoxia off the Changjiang (Yangtze River) Estuary. Mar. Environ. Res., 77, 1-5, doi: 10.1016/j.marenvres.2011.12.007. [Link]

Watson, R. and D. Pauly, 2001: Systematic distortion in world fisheries catch trends. Nature, 414, 534-536, doi: 10.1038/35107050. [Link]

Webb, W. L., M. Newton, and D. Starr, 1974: Carbon dioxide exchange of Alnus rubra: A mathematical model. Oecologia, 17, 281-291, doi: 10.1007/BF00345747. [Link]

Xie, Y., G. H. Tilstone, C. Widdicombe, E. M. S. Woodward, C. Harris, and M. K. Barnes, 2015: Effect of increases in temperature and nutrients on phytoplankton community structure and photosynthesis in the western English Channel. Mar. Ecol. Prog. Ser., 519, 61-73, doi: 10.3354/meps 11101. [Link] 